\title{
ASPEK HUKUM PEMANFAATAN TEKNOLOGI INFORMASI DALAM PERSPEKTIF UU NOMOR 11 TAHUN 2008 TENTANG INFORMASI DAN TRANSAKSI ELEKTRONIK
}

\author{
Oleh : \\ Go Lisanawati*, Mufidatul Ma'sumah*
}

\begin{abstract}
The use of information technology (IT) at present plays an important role and at last may bear a new society namely the users of IT as a part of information and communication technology society. On the one hand, the development may provide the users with unlimited information. On the other hand, the IT may also be misused for crimes. In this condition, law should be able to serv some protection for their users.
\end{abstract}

Kata Kunci: pemanfaatan teknologi informasi, aspek hukum, UU No 11 tahun 2008

\section{PENDAHULUAN}

Perkembangan jaman yang semakin modern membutuhkan penyebaran akan informasi yang cepat dan tepat. Perkembangan yang semakin modern atas bantuan informasi yang tidak terbatas tersebut membawa tuntutan bagi peningkatan kualitas hidup manusia itu sendiri. Hal tersebut pada akhirnya membawa perubahan perilaku di dalam masyarakat, dan kemudian membentuk serta menciptakan suatu komunitas baru yang dinamakan sebagai Information and Communication Technology (ICT) Society. Teknologi informasi dan komunikasi telah berkembang dengan pesat di seluruh dunia, termasuk di Indonesia dengan atau tanpa disadari. Hal tersebut ditandai dengan munculnya beragam bentuk inovasi teknologi dan fasilitasfasilitas kemudahan mengakses informasi, misalnya dengan hadirnya Interconnected Network (Internet).

\footnotetext{
* Dosen Fakultas Hukum Universitas Surabaya.

* Dosen Fakultas Hukum Universitas Widyagama Malang
}

Valadskakis kemudian menyatakan: "The Internet opened up service markets that were previously protected by geographical distance". (Valadskakis, 1998). Mardjono Reksodiputro memberikan pernyataan sebagai berikut:

Sungguh mengagumkan dampak dan perkembangan Teknologi Informasi (TI) bagi kita semua. Begitu cepat TI berkembang sehingga sulit untuk mengikutinya. Kemajuan TI tersebut menawarkan kemudahan. Misalnya melalui Internet Banking...

Kemudahan tersebut, tidak datang tanpa adanya resiko. Penggunaan internet yang semakin marak, mendorong sebagian orang untuk menguntungkan diri sendiri atau merugikan orang lain di cyberspace... (Petrus Reinhard Golose, 2008:xvi)

Keberadaan internet tersebut kemudian dimanfaatkan untuk melakukan cyber activities (kegiatan siber) baik dalam konteks positifmaupun negatif.

Keberadaan ICT Society sebenarnya juga tidak dapat dipisahkan dengan Globalisasi. Globali- 
sasi memiliki makna yang sangat luas dan tidak terbatas pada suatu arti tertentu. Artinya makna globalisasi adalah multi perspektif, baik dari segi hukum, segi ekonomi, segi budaya, dsb. Globalisasi pada dasarnya merupakan suatu keterbukaan (openess). Globalisasi telah mengecilkan bahkan menghapuskan batas-batas wilayah Negara yang berarti membuka komunikasi dan dialog global tanpa batas waktu dan ruang. Rambe, dalam Abdul Wahid dan Muhammad Labib, menyatakan bahwa secara teoritis, globalisasi bertujuan untuk menciptakan interdependensi ekonomi antar seluruh negara di dunia, melalui peningkatan volume dan transaksi perdagangan lintas negara serta arus modal Internasional (Abdul Wahid dan Mohammad Labib, 2005:5). Dengan meminjam istilah Abdul Wahid dan Muhammad Labib, dapat dinyatakan bahwa ada 'rumah baru' bagi manusia dan bangsa-bangsa dunia melalui kehadiran teknologi informasi dalam era globalisasi ini. Nampaknya 'rumah baru' itu dapat memberikan kenyamanan di satu sisi, dan di sisi lain rumah baru tersebut juga sudah diincar oleh pencuri yang hendak melakukan kejahatan. Pada posisi yang sedemikian kompleks, ternyata kecanggihan informasi dan teknologi tersebut membawa dampak signifikan bagi manusia, baik yang terwujud sebagai dampak positif dan dampak negatif. Bahkan kecenderungan terjadinya kejahatan tersebut sangat luar biasa. Suatu situs menyebutkan bahwa pada setiap 1 detik itu dapat terjadi 4 kejahatan siber. Artinya bahwa kejahatan siber mulai muncul mengancam kehidupan manusia.

Globalisasi mulai berkembang pada abad Ke15. Joyce S. Osland mencatat dan memberikan penjelasan sebagai berikut:

The roots of globalization began to take hold in the $15^{\text {th }}$ century with voyages by intrepid explorers, funded by European monarchs seeking new trade routes. It continued throughout the years of the imperial expansion of Europe, the colonization of other lands primarily for the purpose of trade. In the mercantilist era, trading companies (such as the Hudson Bay Company and the East India Tea Company) served as surrogate colonial governments, merging trade and government. Later on, trading companies were privatized, and intercontinental railways and transoceanic steamships made it possible to open previously protected markets. The global markets present in the early 1900s were disrupted by both World Wars. After World War II, the World Bank and the International Monetary Fund were founded to aid development in war-ravaged countries and lesserdeveloped nations ( $L D C s$ ). The English term "globali- zation" first made its appearance around 1960 (Waters, 1995). In 1995 the World Trade Organization (WTO) was created, as a successor to the General Agreement on Tariffs and Trade (GATT), "to help trade flow smoothly, freely, fairly and predictably." In recent years many nations have liberalized their trade policies removing trade barriers and focusing on exports, which further stimulated globalization. (Joyce S. Osland, 2002:3)

Penjelasan Umum UU No. 11 Tahun 2008, alinea 1 , menegaskan sebagai berikut:

Pemanfaatan Teknologi Informasi, media, dan komunikasi telah mengubah baik perilaku masyarakat maupun peradaban manusia secara global. Perkembangan teknologi informasi dan komunikasi telah pula menyebabkan hubungan dunia menjadi tanpa batas (borderless) dan menyebabkan perubahan sosial, ekonomi dan budaya secara signifikan berlangsung demikian cepat. Teknologi Informasi saat ini menjadi pedang bermata dua karena selain memberikan kontribusi bagi peningkatan kesejahteraan, kemajuan, dan peradaban manusia, sekaligus menjadi sarana efektif perbuatan melawan hukum.

Penjelasan-penjelasan di atas menunjukkan bahwasanya pada setiap perkembangan di dalam masyarakat, terkait dengan hal ini adalah perkembangan masyarakat yang baru yang disebabkan adanya perkembangan teknologi infromasi, selalu memiliki sisi kelebihan atau keunggulan dan sekaligus sisi kekurangan atau kelemahan. Dunia baru yang virtual menjalankan kegiatan teknologi informasi, media dan komunikasi harus diikuti pula dengan aturan yang akan melindunginya, yaitu yang disebut dengan hukum telematika atau cyber law atau hukum siber. Kejahatan yang ditimbulkan seringkali disebut sebagai kejahatan siber atau cyber crime ataupun tindak pidana dunia maya. Kejahatan siber ini tidak jarang juga menjadi pemicu terjadinya kejahatan bisnis. Sutan Remy Sjahdeini menegaskan bahwa "ekses negatifdari kemajuan teknologi, yaitu mengakibatkan munculnya jenis-jenis kejahatan bisnis (Business Crime), yang modus operandi dari kejahatan-kejahatan tersebut dahulu tidak pernah dikenal atau tidak pernah dilakukan oleh para penjahat dan pelaku bisnis, ternyata muncul". (Romli Atmasasmita, 2003: xii-xiii).

Pemahaman mengenai kejahatan siber atau cyber crime tersebut dapat diketahui dari pendapat para ahli. V.D. Dudeja mengemukakan pendapatnya sebagai berikut:

Cyber crime refers to criminal activities taking place in computer and computer networks. Knowingly or 
intentionally accesses and without permission alters, damages, delets, destroys, or otherwise uses any data, computer data, computer system or computer networkin order to devise or execute any unlawful scheme or wrongfully control or obtain money... A student unleash the 'I Love You' being over the internet. The story made it to cover of the TIME magazine... ( V.D. Dudeja, 2002: 169)

Karakteristik Cyber crime dicirikan sebagai sesuatu yang berkarakter khusus, yang berbeda dengan karakteristik kejahatan yang ada di dunia nyata. Oleh karenanya masih menjadi perdebatan apakah kejahatan siber itu an old wine in the new bottle ataukah benar-benar a new wine in the new bottle. Susan W. Brener dalam penjelasannya menyatakan sebagai berikut:

The traditional model of law enforcement, which is the model still in use today, evolved to deal with real-world crime; the essential components of the model were, for all intents and purposes, in place by the nineteenth century. Real-world crime is crime perpetrated in and via the real, physical world, that is, without the use of technology... Primarily because it is situated in a corporeal, physical environment, real-world crime has several defining characteristics. The sections below identify and examine the four characteristics that are the most significant... Cyber crime differs from realworld "crime" in another important regard: It is not one-to-one "crime" because it is not corporeal crime, not terrestrial crime; consequently, the one-to-one scale of offense commission is by no means a viable default assumption for cyber crime... (Susan W. Brener, 2004: 1-2, 7)

Dikdik M. Arief Mansur dan Elisatris Gultom menambahan bahwa karakteristik cyber crime adalah:

1. Non Violence (tanpa kekerasan);

2. Sedikit melibatkan kontak fisik (minimize of physical contact);

3. Menggunakan peralatan (equipment) dan teknologi;

4. Memanfaatkan jaringan telematika (telekomunikasi, media dan informatika) global (Dikdik M. Arief Mansur dan Elisatris Gultom, 2005:27)

Kehadiran UUNo. 11 Tahun 2008 telah membangun rezim hukum baru, yaitu rezim hukum siber atau hukum telematika. Sebelum adanya UU No. 11 Tahun 2008, maka penanganan atas tindak pidana-tindak pidana di dunia maya selama ini dilakukan dẻngan menggunakan perangkat hukum yang ada, misalnya dengan menggunakan Undangundang Nomor 19 Tahun 2002 tentang Hak Cipta, Undang-undang Nomor 36 Tahun 1999 tentang
Telekomunikasi, maupun undang-undang khusus lainnya. Dengan hadirnya UU No. 11 Tahun 2008 diharapkan dapat memberikan kepastian hukum dalam berbagai aktivitas terkait dengan pemanfaatan teknologi informasi dan komunikasi tersebut.

\section{Asas dan Tujuan Pemanfaatan Teknologi Infor- masi dalam UU No. 11 Tahun 2008}

Kehadiran UU No. 11 Tahun 2008 yang telah disahkan pada Bulan April 2008 yang lalu, dinyatakan sebagai upaya keseriusan Pemerintah Indonesia untuk menanggulangi terjadinya perbuatan-perbuatan melawan hukum maupun tindak pidana yang terjadi, dan yang telah menempatkan Indonesia dalam peringat top five sebagai negara terbesar kriminalitas di bidang siber. Roy Suryo, mengutip data statistik dari sebuah research yang dilakukan oleh clearcommerce.com, memberikan penjelasan bahwa Indonesia menduduki peringkat ke dua untuk penyalahgunaan internet, satu tingkat di bawah Ukraina, dan sangat kontras dengan data statistik tentang penggunaan internet di dunia. Data dari AC Nielsen menyatakan bahwa penggunaan internet di Indonesia hanya sekitar 1\% dari keseluruhan penggunaan internet di dunia (Roy Suryo, 2008).

Hal tersebut sebenarnya sejalan dengan pernyataan dari Penjelasan Umum UU No. 11 Tahun 2008, yang menyatakan bahwa pada dasarnya Teknologi Informasi saat ini menjadi pedang bermata dua, di mana selain memberikan kontribusi bagi peningkatan kesejahteraan, kemajuan dan peradaban manusia, sekaligus menjadi sarana efektif perbuatan melawan hukum. Menteri Komunikasi dan Informatika, Muhammad Nuh, dalam sambutannya menjelaskan lebih lanjut bahwa manifestasi perbuatan hukum di dunia maya sangat mengkhawatirkan. Hal tersebut dengan mengingat pula bahwa tindakan carding, hacking, cracking, phising, booting, viruses, cybersquatting, perjudian, penipuan, terorisme, dan penyebaran informasi destruktif telah menjadi bagian dari aktivitas pelaku kejahatan di dunia maya.

Secara filosofis UU No. 11 Tahun 2008 hadir sebagai upaya untuk melaksanakan pembangunan hukum. Pada dasar menimbang butir a UU No. 11 Tahun 2008 dinyatakan bahwa pembangunan nasional adalah suatu proses berkelanjutan yang 
harus senantiasa tanggap terhadap berbagai dinamika yang terjadi di masyarakat. Dinamika tersebut pada dasarnya juga meliputi perkembangan ilmu pengetahuan, teknologi informasi dan komunikasi yang telah mengalami perkembangan yang luar biasa, khususnya muncul dan bercampur dengan globalisasi yang telah memberikan kenyamana bagi manusia. Untuk selanjutnya dapat dijelaskan bahwa globalisasi informasi telah menempatkan Indonesia sebagi bagian dari masyarakat informasi dunia sehingga mengharuskan dibentuknya pengaturan mengenai pengelolaan Informasi dan Transaksi Elektronik di tingkat nasional sehingga pembangunan Teknologi Informasi dapat dilakukan secara optimal, merata, dan menyebar ke seluruh lapisan masyarakat guna mencerdaskan kehidupan bangsa (vide butir b dasar menimbang UU No. 11 Tahun 2008). Pada hakikatnya kehadiran globalisasi informasi dan teknologi menempatkan Indonesia sebagai bagian dari kesatuan negara di dunia menjadi bagian dari masyarakat informasi, yang berada dalam lingkungan tidak tersekat-sekat dengan negara manapun di dunia. Demi menjaga keberadaan tersebut, maka mengharuskan Indonesia membentuk pengaturan hukum di bidang informasi dan teknologi tersebut. Keharusan tersebut mengingat akan perkembangan dan kemajuan teknologi telah mengubah berbagai aspek kehidupan manusia dewasa ini. Sejalan dengan dasar menimbang butir c, maka diingat pula bahwa perkembangan dan kemajuan Teknologi Informasi yang demikian pesat telah mmenyebabkan perubahan kegiatan kehidupan manusia dalam berbagai bidang secara langsung mempengaruhi lahirnya bentukbentuk perbuatan hukum baru. Pengundangan UU No. 11 Tahun 2008 tersebut pada dasarnya dikonsepkan dan ditujukan untuk perwujudan upaya menjaga, memelihara, dan memperkukuh persatuan dan kesatuan nasional demi kepentingan nasional (vide dasar menimbang butir d), serta mewujudkan kesejahteraan masyarakat (vide dasar menimbang butire). Kepentingan nasional yang dimaksud dalam hal ini adalah kepentingan memberikan perlindungan terhadap masyarakat atas perbuatan-perbuatan melawan hukum yang memiliki kecenderungan mengarah pada suatu tindak pidana, yang mempunyai sifat hakikat, bentuk manifestasi dan akibat hukum yang berbeda dengan tindak pidana yang terjadi dalam dunia nyata.
Dengan memberikan perlindungan tersebut maka diharapkan dapat terwujud kesejahteraan masyarakat. Menilik pada permasalahan tindak pidana di dunia siber tersebut, maka Pemerintah perlu mendukung pengembangan Teknologi Informasi melalui infrastrukturhukum dan pengaturannya sehingga pemanfaatan Teknologi Informasi dilakukan secara aman untuk mencegah penyalahgunaannya dengan memperhatikan nilai-nilai agama dan sosial budaya masyarakat Indonesia. (vide dasar menimbang butir fUUNo. 11 Tahun 2008). Melalui dasar menimbang butir f tersebut tersirat sebagai suatu dasar pemaknaan bahwa UU No. 11 Tahun 2008 memiliki dimensi hukum pidana, khususnya dalam hal tersebut ditujukan pada upaya pencegahan penyalahgunaan Teknologi Informasi melalui penggunaan hukum pidana.

Ketentuan Pasal 3 menentukan bahwa: "Pemanfaatan Teknologi Informasi dan Transaksi Elektronik dilaksanakan berdasarkan asas kepastian hukum, manfaat, kehati-hatian, iktikad baik, dan kebebasan memilih teknologi atau netral teknologi". Penjelasan Pasal 3 mendefinisikan masing-masing asas tersebut adalah sebagai berikut:

\begin{abstract}
"Asas kepastian hukum" berarti landasan hukum bagi pemanfaatan Teknologi Informasi dan Transaksi Elektronik serta segala sesuatu yang mendukung penyelenggaraannya yang mendapatkan pengakuan hukum di dalam dan di luar pengadilan. "Asas manfaat" berarti asas bagi pemanfaatan Teknologi Informasi dan Transaksi Elektronik diupayakan untuk mendukung proses berinformasi sehingga dapat meningkatkan kesejahteraan masyarakat. "Asas kehati-hatian" berarti landasan bagi pihak yang bersangkutan harus memperhatikan segenap aspek yang berpotensi mendatangkan kerugian, baik bagi dirinya maupun bagi pihak lain dalam pemanfaatan Teknologi Informasi dan Transaksi Elektronik.

"Asas itikad baik" berarti asas yang digunakan para pihak dalam melakukan Transaksi Elektronik tidak bertujuan untuk secara sengaja dan tanpa hak atau melawan hukum mengakibatkan kerugian bagi pihak lain tanpa sepengetahuan pihak lain tersebut. "Asas kebebasan memilih teknologi atau netral teknologi" berarti asas pemanfaatan Teknologi Informasi dan Transaksi Elektronik tidak terfokus pada penggunaan teknologi tertentu sehingga dapat mengikuti perkembangan pada masa yang akan datang.
\end{abstract}

Dengan demikian di dalam memanfaatkan teknologi Informasi, maka harus dilandaskan pada Asas Kepastian Hukum, Asas Manfaat, Asas Kehati-hatian, Asas Itikad Baik, Asas Kebebasan 
Widya Yuridika Jurnal Hukum, Volume 2 / Nomor 1 / Juni 2019

memilih teknologi atau netral teknologi. Keseluruhan asas tersebut menjadi pendukung terciptanya rezim hukum telematika yang baik.

Tujuan Pemanfaatan Teknologi Informasi dapat dilihat dari ketentuan Pasal 4, yang menyatakan sebagai berikut:

Pemanfaatan Teknologi Informasi dan Transaksi Elektronik dilaksanakan dengan tujuan untuk:

a. mencerdaskan kehidupan bangsa sebagai bagian dari masyarakat informasi dunia;

b. mengembangkan perdagangan dan perekonomian nasional dalam rangka meningkatkan kesejahteraan masyarakat;

c. meningkatkan efektivitas dan efisiensi pelayanan publik;

d. membuka kesempatan seluas-luasnya kepada setiap Orang untuk memajukan pemikiran dan kemampuan di bidang penggunaan dan pemanfaatan Teknologi Informasi seoptimal mungkin dan bertanggung jawab; dan

e. memberikan rasa aman, keadilan, dan kepastian hukum bagi pengguna dan penyelenggara Teknologi Informasi.

Sebagaimana dijelaskan di dalam ketentuan Pasal 4 tersebut, pada intinya setiap teknologi informasi dan transaksi elektronik yang dilakukan harus sejalan dengan tujuan negara yaitu untuk mencerdaskan kehidupan bangsa. Dengan transaksi elektronik yang berkembang pesat akan mampu meningkatkan kesejahteraan masyarakat, khususnya dalam hal ini adalah untuk pengembangan perdagangan dan perekonomian nasional.

\section{Perlindungan Yang Diberikan Dalam UU No. 11 Tahun 2008}

Ketentuan di dalam UU No. 11 Tahun 2008 tersebut pada dasarnya ditujukan untuk memberikan perlindungan kepada setiap Orang (-pen), baik perseorangan maupun badan usaha) yang melaksanakan kegiatan pemanfaataan teknologi informasi maupun melakukan kegiatan transaksi elektronik.

Perlindungan tersebut adalah sebagai berikut:

- Perlindungan atas pemilik nama domain (baik penyelenggara negara, orang, badan usaha, masyarakat) yang beritikad baik, tidak melanggar prinsip persaingan usaha secara sehat, dan tidak melanggar hak orang lain (vide Pasal 23)

- Perlindungan atas informasi elektronik dan/atau dokumen elektronik yang disusun menjadi karya intelektual, situs intelektual dan karya intelektual yang dilindungi sebagai HaKI (vide Pasal 25)

- Perlindungan atas data pribadi seseorang (vide Pasal 26 dan penjelasannya)

\section{Bentuk-bentuk Perbuatan Yang Dilarang dan Ancaman Sanksi Pidananya}

Telah diuraikan di atas bahwasanya di dalam upaya pemanfaatan teknologi informasi dan transaksi elektronik tersebut dapat terjadi berbagai macam pelanggaran, atau yang kemudian di dalam UUNo. 11 Tahun 2008 pelanggaran tersebut dikategorikan sebagai suatu tindak pidana.

Penjelasan mengenai bentuk perbuatan yang dilarang dan ancaman sanksi pidananya adalah sebagai berikut:

\section{Pasal 27:}

(1) Setiap Orang dengan sengaja dan tanpa hak mendistribusikan dan/atau mentransmisikan dan/ atau membuat dapat diaksesnya Informasi Elektronik dan/atau Dokumen Elektronik yang memiliki muatan yang melanggar kesusilaan.

(2) Setiap Orang dengan sengaja dan tanpa hak mendistribusikan dan/atau mentransmisikan dan/ atau membuat dapat diaksesnya Informasi Elektronik dan/atau Dokumen Elektronik yang memiliki muatan perjudian.

(3) Setiap Orang dengan sengaja dan tanpa hak mendistribusikan dan/atau mentransmisikan dan/ atau membuat dapat diaksesnya Informasi Elektronik dan/atau Dokumen Elektronik yang memiliki muatan penghinaan dan/atau pencemaran nama baik.

(4) Setiap Orang dengan sengaja dan tanpa hak mendistribusikan dan/atau mentransmisikan dan/ atau membuat dapat diaksesnya Informasi Elektronik dan/atau Dokumen Elektronik yang memiliki muatan pemerasan dan/atau pengancaman.

Ketentuan pasal 27 tersebut memiliki unsurunsur delik sebagai berikut:

Unsur Subjektif:

- Memiliki bentuk kesalahan, yaitu berupa sengaja dan tanpa hak. 
Unsur Objektif:

- Mendistribusikan dan/atau mentransmisikan dan/atau membuat dapat diaksesnya Informasi Elektronik dan/atau Dokumen Elektronik

- Informasi Elektronik dan/atau Dokumen Elektronik yang memiliki muatan: melanggar kesusilaan (vide ayat (1)), perjudian (vide ayat (2)), penghinaan dan/atau pencemaran nama baik (vide ayat (3)), pemerasan dan/atau kekerasan (vide ayat (4)).

UU No. 11 Tahun 2008 tidak memberikan penjelasan lebih lanjut mengenai makna muatan yang dilarang tersebut, baik yang mengenai content kesusilaan, perjudian, penghinaan dan/atau pencemaran nama baik, pemerasan dan/atau kekerasan. Untuk itu harus merujuk pada peraturan lainnya yang ada di dalam undang-undang lain. Untuk itu di sini harus digunakan penafsiran sistematis, yaitu dengan merujuk pada pasal-pasal di dalam ketentuan KUHP dan undang-undang lain, seperti Undang Undang Nomor 44 Tahun 2008 tentang Pornografi (untuk pelanggaran kesusilàan)

\section{Pasal 28:}

(1) Setiap Orang dengan sengaja dan tanpa hak menyebarkan berita bohong dan menyesatkan yang mengakibatkan kerugian konsumen dalam Transaksi Elektronik.

(2) Setiap Orang dengan sengaja dan tanpa hak menyebarkan informasi yang ditujukan untuk menimbulkan rasa kebencian atau permusuhan individu dan/atau kelompok masyarakat tertentu berdasarkan atas suku, agama, ras, dan antar golongan (SARA)

Unsur-unsur delik dalam Pasal 28 adalah:

Unsur Subjektif:

- Bentuk kesalahan yang berupa sengaja dan tanpa hak

\section{Unsur Objektif:}

- Menyebarkan berita bohong dan menyesatkan yang mengakibatkan kerugian konsumen dalam Transaksi Elektronik (vide ayat (1));

- Menyebarkan informasi yang ditujukan untuk menimbulkan rasa kebencian atau permusuhan individu dan/atau kelompok masyarakat tertentu berdasarkan atas suku, agama, ras dan antar golongan (SARA)
Pasal 29: "Setiap Orang dengan sengaja dan tanpa hak mengirimkan Informasi Elektronik dan/atau Dokumen Elektronikyang berisi ancaman kekerasan atau menakut-nakuti yang ditujukan secara pribadi”.

Unsur-unsur deliknya adalah:

- Setiap orang

- Dengan sengaja dan tanpa hak

- Mengirimkan Informasi Elektronik dan/atau Dokumen Elektronik

- Berisi ancaman kekerasan atau menakuti-nakuti yang ditujukn secara pribadi.

Ketentuan Pasal 27 ayat (4) apabila dibandingkan dengan ketentuan Pasal 29 sebenarnya memiliki persamaan dengan tanpa memberikan penjelasan lebih lanjut. Yang membedakan hanyalah pada Pasal 29 ancaman kekerasan itu ditujukan secara pribadi. Hal tersebut sulit mengingat di dalam aktivitas dunia maya, batas-batas pribadi dan publik tidak tampak secara jelas. Seharusnya UU memberikan penjelasan lebih lanjut mengenai batas pembedanya.

\section{Pasal 30:}

(1) Setiap Orang dengan sengaja dan tanpa hak atau melawan hukum mengakses Komputer dan/atau Sistem Elektronik milik Orang lain dengan cara apa pun.

(2) Setiap Orang dengan sengaja dan tanpa hak atau melawan hukum mengakses Komputer dan/atau Sistem Elektronik dengan cara apa pun dengan tujuan untuk memperoleh Informasi Elektronik dan/atau Dokumen Elektronik.

(3) Setiap Orang dengan sengaja dan tanpa hak atau melawan hukum mengakses Komputer dan/atau Sistem Elektronik dengan cara apa pun dengan melanggar, menerobos, melampaui, atau menjebol sistem pengamanan.

Unsur-unsur deliknya adalah:

Unsur Subjektif:

- Memiliki bentuk kesalahan berupa kesengajaan dan tanpa hak atau melawan hukum

Unsur Objektif:

- Mengakses Komputer dan/atau SistemElektronik

- Dilakukan dengan cara apapun

Pada ayat (1) ditekankan pada adanya perbuatan melawan hukum mengakses Komputer dan/ 
atau Sistem Elektronik milik orang lain (cetak tebal oleh penulis).

Pada ayat (2), ditegaskan adanya unsur tujuan, yaitu ditujukan untuk untuk memperoleh Informasi elektronik dan/atau Dokumen elektronik.

Ketentuan Pasal 30 ayat (3) tidak ditegaskan bahwa Komputer dan/atau Sistem Elektronik itu milik orang lain. Hal tersebut cukup menimbulkan kesulitan, karena tidak mungkin perbuatan melawan hukum tersebut dilakukan oleh pelaku terhadap komputer dan/atau sistem elektronik milik pelaku sendiri. Ketentuan Pasal 30 ayat (3) juga menimbulkan makna bias dan multiinterpretasi pada ayat (1) dan (2), yaitu dengan menjelaskan bahwa cara apapun itu dilakukan dengan kegiatan melanggar, menerobos, melampaui, menjebol sistem pengamanan. Secara normal, cara orang melakukan akses secara tanpa hak biasanya dilakukan dengan cara melanggar, menerobos, melampaui, ataupun menjebol sistem pengamanan. Dengan demikian harus diperjelas mengapa ketentuan ayat (3) ditambahkan di dalam Pasal 30 tersebut.

\section{Pasal 31:}

(1) Setiap Orang dengan sengaja dan tanpa hak atau melawan hukum melakukan intersepsi atau penyadapan atas Informasi Elektronik dan/atau Dokumen Elektronik dalam suatu Komputer dan/atau Sistem Elektronik tertentu milik Orang lain.

(2) Setiap Orang dengan sengaja dan tanpa hak atau melawan hukum melakukan intersepsi atas transmisi Informasi Elektronik dan/atau Dokumen Elektronik yang tidak bersifat publik dari, ke, dan di dalam suatu Komputer dan/atau Sistem Elektronik tertentu milik Orang lain, baik yang tidak menyebabkan perubahan apa pun maupun yang menyebabkan adanya perubahan, penghilangan, dan/atau penghentian Informasi Elektronik dan/atau Dokumen Elektronik yang sedang ditransmisikan.

(3) Kecuali intersepsi sebagaimana dimaksud pada ayat (1) dan ayat (2), intersepsi yang dilakukan dalam rangka penegakan hukum atas permintaan kepolisian, kejaksaan, dan/atau institusi penegak hukum lainnya yang ditetapkan berdasarkan undang-undang.
(4) Ketentuan lebih lanjut mengenai tata cara intersepsi sebagaimana dimaksud pada ayat (3) diatur dengan Peraturan Pemerintah.

\section{Pasal 32:}

(1) Setiap Orang dengan sengaja dan tanpa hak atau melawan hukum dengan cara apa pun mengubah, menambah, mengurangi, melakukan transmisi, merusak, menghilangkan, memindahkan, menyembunyikan suatu Informasi Elektronik dan/atau Dokumen Elektronik milik Orang lain atau milik publik.

(2) Setiap Orang dengan sengaja dan tanpa hak atau melawan hukum dengan cara apa pun memindahkan atau mentransfer Informasi Elektronik dan/atau Dokumen Elektronik kepada Sistem Elektronik Orang lain yang tidak berhak.

(3) Terhadap perbuatan sebagaimana dimaksud pada ayat (1) yang mengakibatkan terbukanya suatu Informasi Elektronik dan/atau Dokumen Elektronik yang bersifat rahasia menjadi dapat diakses oleh publik dengan keutuhan data yang tidak sebagaimana mestinya.

Pasal 33: "Setiap Orang dengan sengaja dan tanpa hak atau melawan hukum melakukan tindakan apa pun yang berakibat terganggunya Sistem Elektronik dan/atau mengakibatkan Sistem Elektronik menjadi tidak bekerja sebagaimana mestinya".

Unsur-unsur deliknya adalah:

- Setiap orang

- Dengan sengaja dan tanpa hak atau melawan hukum

- Melakukan tindakan apapun yang berakibat terganggunya Sistem Elektronik dan/atau mengakibatkan Sistem Elektronik menjadi tidak bekerja sebagaimana mestinya

\section{Pasal 34:}

(1) Setiap Orang dengan sengaja dan tanpa hak atau melawan hukum memproduksi, menjual, mengadakan untuk digunakan, mengimpor, mendistribusikan, menyediakan, atau memiliki:

a. perangkat keras atau perangkat lunak Komputer yang dirancang atau secara khusus dikembangkan untuk memfasilitasi perbuatan sebagaimana dimaksud dalam Pasal 27 sampai dengan Pasal 33; 
b. sandi lewat Komputer, Kode Akses, atau hal yang sejenis dengan itu yang ditujukan agar Sistem Elektronik menjadi dapat diakses dengan tujuan memfasilitasi perbuatan sebagaimana dimaksud dalam Pasal 27 sampai dengan Pasal 33.

(2) Tindakan sebagaimana dimaksud pada ayat (1) bukan tindak pidana jika ditujukan untuk melakukan kegiatan penelitian, pengujian Sistem Elektronik, untukperlindungan Sistem Elektronik itu sendiri secara sah dan tidak melawan hukum.

\section{Pasal 35:}

Setiap Orang dengan sengaja dan tanpa hak atau melawan hukum melakukan manipulasi, penciptaan, perubahan, penghilangan, pengrusakan Informasi Elektronik dan/atau Dokumen Elektronik dengan tujuan agar Informasi Elektronik dan/atau Dokumen Elektronik tersebut dianggap seolah-olah data yang otentik.

Pasal 36: "Setiap Orang dengan sengaja dan tanpa hak atau melawan hukum melakukan perbuatan . sebagaimana dimaksud dalam Pasal 27 sampai dengan Pasal 34 yang mengakibatkan kerugian bagi Orang lain".

Ketentuan dalam Pasal 36 tidak jelas karena setiap kegiatan yang dilakukan secara sengaja dan tanpa hak atau melawan hukum terhadap perbuatanperbuatan atas suatu Komputer dan/atau Sistem Elektronik menimbulkan kerugian bagi korban, seberapapun kecil kerugiannya. Hal tersebut dapat memunculkan makna yang berbeda-beda dalam penerapannya.

Berkaitan dengan perbuatan-perbuatan yang dilarang tersebut, Undang-Undang juga mengatur mengenai ketentuan pidananya, yaitu:

\section{Pasal 45:}

(1) Setiap Orang yang memenuhi unsur sebagaimana dimaksud dalam Pasal 27 ayat (1), ayat (2), ayat (3), atau ayat (4) dipidana dengan pidana penjara paling lama 6 (enam) tahun dan/atau denda paling banyak Rp1.000.000.000,00 (satu miliar rupiah).

(2) Setiap Orang yang memenuhi unsur sebagaimana dimaksud dalam Pasal 28 ayat (1) atau ayat (2) dipidana dengan pidana penjara paling lama 6 (enam) tahun dan/atau denda paling banyak Rp1.000.000.000,00 (satu miliar rupiah).

(3) Setiap Orang yang memenuhi unsur sebagaimana dimaksud dalam Pasal 29 dipidana dengan pidana penjara paling lama 12 (dua belas) tahun dan/atau denda paling banyakRp2.000.000.000,00 (dua miliar rupiah).

\section{Pasal 46:}

(1) Setiap Orang yang memenuhi unsur sebagaimana dimaksud dalam Pasal 30 ayat (1) dipidana dengan pidana penjara paling lama 6 (enam) tahun dan/atau denda paling banyak Rp600.000.000,00 (enam ratus juta rupiah).

(2) Setiap Orang yang memenuhi unsur sebagaimana dimaksud dalam Pasal 30 ayat (2) dipidana dengan pidana penjara paling lama 7 (tujuh) tahun dan/atau denda paling banyak Rp700.000.000,00 (tujuh ratus juta rupiah).

(3) Setiap Orang yang memenuhi unsur sebagaimana dimaksud dalam Pasal 30 ayat (3) dipidana dengan pidana penjara paling lama 8 (delapan) tahun dan/atau denda paling banyak Rp800.000.000,00 (delapan ratus juta rupiah).

Pasal 47: "Setiap Orang yang memenuhi unsur sebagaimana dimaksud dalam Pasal 31 ayat (1) atau ayat (2) dipidana dengan pidana penjara paling lama 10 (sepuluh) tahun dan/atau denda paling banyak Rp800.000.000,00 (delapan ratus juta rupiah)".

\section{Pasal 48:}

(1) Setiap Orang yang memenuhi unsur sebagaimana dimaksud dalam Pasal 32 ayat (1) dipidana dengan pidana penjara paling lama 8 (delapan) tahun dan/atau denda paling banyak Rp2.000.000.000,00 (dua miliar rupiah).

(2) Setiap Orang yang memenuhi unsur sebagaimana dimaksud dalam Pasal 32 ayat (2) dipidana dengan pidana penjara paling lama 9 (sembilan) tahun dan/atau denda paling banyak Rp3.000.000.000,00 (tiga miliar rupiah).

(3) Setiap Orang yang memenuhi unsur sebagaimana dimaksud dalam Pasal 32 ayat (3) dipidana dengan pidana penjara paling lama 10 (sepuluh) tahun dan/atau denda paling banyak Rp5.000.000.000,00 (lima miliar rupiah). 
Widya Yuridika Jurnal Hukum, Volume 2 / Nomor 1 / Juni 2019

Pasal 49: "Setiap Orang yang memenuhi unsur sebagaimana dimaksud dalam Pasal 33, dipidana dengan pidana penjara paling lama 10 (sepuluh) tahun dan/atau denda paling banyak Rp10.000.000.000,00 (sepuluh miliar rupiah)".

Pasal 50: "Setiap Orang yang memenuhi unsur sebagaimana dimaksud dalam Pasal 34 ayat (1) dipidana dengan pidana penjara paling lama 10 (sepuluh) tahun dan/atau denda paling banyak Rp10.000.000.000,00 (sepuluh miliar rupiah)".

\section{Pasal 51:}

(1) Setiap Orang yang memenuhi unsur sebagaimana dimaksud dalam Pasal 35 dipidana dengan pidana penjara paling lama 12 (dua belas) tahun dan/atau denda paling banyak Rp12.000.000.000,00 (dua belas miliar rupiah).

(2) Setiap Orang yang memenuhi unsur sebagaimana dimaksud dalam Pasal 36 dipidana dengan pidana penjara paling lama 12 (dua belas) tahun dan/atau denda paling banyak Rp12.000.000.000,00 (dua belas miliar rupiah).

\section{Pasal 52:}

(1) Dalam hal tindak pidana sebagaimana dimaksud dalam Pasal 27 ayat (1) menyangkut kesusilaan atau eksploitasi seksual terhadap anak dikenakan pemberatan sepertiga dari pidana pokok.

(2) Dalam hal perbuatan sebagaimana dimaksud dalam Pasal 30 sampai dengan Pasal 37 ditujukan terhadap Komputer dan/atau Sistem Elektronik serta Informasi Elektronik dan/atau Dokumen Elektronik milik Pemerintah dan/atau yang digunakan untuk layanan publik dipidana dengan pidana pokok ditambah sepertiga.

(3) Dalam hal perbuatan sebagaimana dimaksud dalam Pasal 30 sampai dengan Pasal 37 ditujukan terhadap Komputer dan/atau Sistem Elektronik serta Informasi Elektronik dan/atau Dokumen Elektronik milik Pemerintah dan/atau badan strategis termasuk dan tidak terbatas pada lembaga pertahanan, bank sentral, perbankan, keuangan, lembaga internasional, otoritas penerbangan diancam dengan pidana maksimal ancaman pidana pokok masing-masing Pasal ditambah dua pertiga.

(4) Dalam hal tindak pidana sebagaimana dimaksud dalam Pasal 27 sampai dengan Pasal 37 dilaku- kan oleh korporasi dipidana dengan pidana pokok ditambah dua pertiga.

Pemberatan pidana diberikan kepada pelaku kejahatan di bidang teknologi informasi dengan dua macam pemberatan, yaitu pemberatan sebesar $1 / 3$ yang dijatuhkan manakala pelaku melakukan pelanggaran terhadap Pasal 27 ayat (1) yaitu kesusilaan dan eksploitasi seksual atas anak, dan pelanggaran atas Pasal 30 sampai dengan Pasal 37 ditujukan terhadap Komputer dan/atau Sistem Elektronik serta Informasi Elektronik dan/atau Dokumen Elektronik milik Pemerintah dan/atau yang digunakan untuk layanan publik.

Pemberatan sebesar 2/3 diterapkan manakala pelaku melanggar ketentuan Pasal 30 sampai dengan Pasal 37 ditujukan terhadap Komputer dan/atau Sistem Elektronik serta Informasi Elektronik dan/ atau Dokumen Elektronik milikPemerintah dan/atau badan strategis termasuk dan tidak terbatas pada lembaga pertahanan, bank sentral, perbankan, keuangan, lembaga internasional, otoritas penerbangan. Pemberatan $2 / 3$ juga dijatuhkan terhadap pelaku yang berupa korporasi.

\section{Penutup}

Permasalahan pemanfaatan teknologi informasi akan memberikan suatu kontribusi yang sangat signifikan di kemudian hari bagi terwujudnya suatu masyarakat yang memiliki kesadaran TI. Oleh karenanya negara harus memberikan perlindungan kepada pengguna TI yang beritikad baik, dan menjauhkan dari ancaman perbuatan dari pengguna TI yang beritikad jahat. Salah satu cara yang seharusnya dapat memberikan perlindungan adalah dengan cara memberikan perumusan pasal yang jelas, tepat, dan tidak bias sesuai dengan asas-asas hukum pidana yang berlaku.

\section{Daftar Bacaan}

\section{Buku-buku}

Abdul Wahid dan Muhammad Labib, 2005, Kejahatan Mayantara (Cyber Crime). Refika Aditama, Bandung

DikdikM. AriefMansur dan Elisatris Gultom, 2005, CyberLawAspek Hukum Teknologi Informasi, Refika Aditama, Bandung 
Widya Yuridika Jurnal Hukum. Volume 2 / Nomor 1 / Juni 2019

Petrus Reinhard Golose, 2008, Seputar Kejahatan Hacking: Teori dan Studi Kasus, Jakarta, Yayasan Pengembangan Kajian Ilmu Kepolisian

Romli Atmasasmita, 2003. Pengantar Hukum Kejahatan Bisnis, Edisi Kedua. Kencana Penada Media, Jakarta

V.D. Dudeja, 2002, Cyber Crimes and Law: Crimes in Cyber Spaces Scams and Frauds, Volume 1, Published by Ajay Verma for Commonwealth Publishers, New Delhi

\section{Makalah-makalah}

Joyce S. Osland, 2002, "Broadening The Debate: The Pros and Cons of Globalization", Paper
Romi Satrio Wahono, "Analisa UU ITE," diakses dari romi-uuite-fasilkomui-24april2008.zip, 24 April 2008

Roy Suryo, 2008, "Cyberlaw", Materi Seminar padaAcara Bedah Buku, yang diselenggarakan oleh Fakultas Hukum Universitas Brawijaya, Malang, pada tanggal 1 July 2008

Susan W. Brener, 2004, "Toward a criminal law for cyberspace: a new model of law enforcement?". Paper, Rutgers Computer and Technology Law Journal

Valaskakis, K, 1998, "The challenge of strategic governance: Can globalization be managed?", Paper. Optimum 28, no. 2, Summer

50 |Aspek Hukum Pemanfaatan Teknologi... 